\title{
PEMANFAATAN TEKNIK AKROSTIK UNTUK MENINGKATKAN KEMAMPUAN MENULIS PUISI SISWA KELAS VIII SMP
}

\author{
Nurul Khairani Abduh \\ Program Studi Pendidikan Bahasa Indonesia, Sekolah Pascasarjana, Universitas Pendidikan Indonesia \\ Jalan Setiabudi 229, Kota Bandung, Jawa Barat \\ Surel: nrl.khairani@student.upi.edu
}

Informasi Artikel:
Dikirim: 17 Januari 2018; Direvisi: 1 Februari 2018; Diterima: 11 Februari 2018
DOI: 10.26858/retorika.v11il.4979
RETORIKA: Jurnal Bahasa, Sastra dan Pengajarannya berada di bawah lisensi
Creative Commons Attribution-NonCommercial 4.0 International License.
ISSN: 2614-2716 (cetak), ISSN: 2301-4768 (daring)
http://ojs.unm.ac.id/retorika

\begin{abstract}
The Utilization of Acrostic Technique to Increase Student Writing Poetry Skill of Class VIII SMP. This study aims to describe the process and the results of learning to write poetry students by using acrostic techniques. This type of research is a classroom action research consisting of two cycles. Data analysis technique is done descriptively quantitative and qualitative. The subjects of this study are teachers and students of class VIII SMP Negeri 22 Makassar. Based on result of the study found that (1) the mastery of learning shows a quality improvement of 14.8 percent and (2) the result of student writing poetry showed an increase from the average value of 75 in cycle one to 80 in cycle two. Based on these results, acrostic technique is recommended for learning to write poetry in JHS.
\end{abstract}

Abstrak. Pemanfaatan Teknik Akrostik untuk Meningkatkan Kemampuan Menulis Puisi Sis wa Kelas VIII SMP. Penelitian ini bertujuan untuk mendeskripsikan peningkatan proses dan hasil pembelajaran menulis puisi dengan menggunakan teknik akrostik. Jenis penelitian ini adalah penelitian tindakan kelas yang terdiri dari dua siklus. Teknik analisis data dilakukan secara deskriptif kuantitatif dan kualitatif. Subjek penelitian ini adalah guru dan siswa kelas VIII SMP Negeri 22 Makassar. Berdasarkan hasil penelitian ditemukan bahwa (1) ketuntasan pembelajaran menunjukkan peningkatan kualitas sebesar 14,8\% dan (2) hasil pembelajaran menulis puisi siswa menunjukkan peningkatan dari nilai rata-rata 75,45 pada siklus I meningkat menjadi 80,05 pada siklus kedua. Berdasarkan hasil tersebut, teknik akrostik direkomendasikan untuk pembelajaran menulis puisi di SMP.

Kata kunci: menulis puisi, teknik akrostik, peningkatan 
Pada hakikatnya, pembelajaran bahasa Indonesia adalah membelajarkan peserta didik tentang keterampilan berbahasa Indonesia yang baik dan benar sesuai tujuan dan fungsinya. Salah satu tujuan mata pelajaran Bahasa Indonesia di sekolah menurut Atzamaki (2013) adalah agar peserta didik menikmati dan memanfaatkan karya sastra untuk memperluas wawasan, budi pekerti, serta meningkatkan pengetahuan dan kemampuan berbahasa, dan menghargai dan membanggakan sastra Indonesia sebagai khazanah budaya dan intelektual manusia Indonesia. Dengan demikian, sastra merupakan salah satu bagian yang tidak terpisahkan dari pengajaran bahasa Indonesia yang tercantum dalam kurikulum.

Sebagaimana tujuan pendidikan nasional yang menghendaki tercapainya keseimbangan antara dimensi jasmaniah dan rohaniah dalam diri siswa, maka proses pendidikan, pengenalan, dan pemahaman terhadap sastra akan dapat memperkaya manusia sebagai pribadi dalam dialog terusmenerus dengan dunia manusia dan kemanusiaan. Dalam konteks inilah sastra berpotensi sebagai pemancar berbagai nilai dan menjadi sumber pengilhaman tentang kebajikan (virtue) dan kebijakan (wisdom) (Hasan dalam Nurgiyantoro \& Efendi, 2013:383).

Berdasarkan pernyataan tersebut, pengajaran sastra, apabila dilakukan dengan teknik-teknik dan strategi-strategi yang tepat akan sangat bermanfaat dalam meningkatkan pengetahuan, mengembangkan daya cipta dan rasa, serta menunjang pembentukan watak dan karakter diri siswa dalam menghadapi berbagai permasalahan nyata dalam masyarakat. Menulis puisi merupakan salah satu kompetensi dasar yang ditetapkan dalam pengajaran bahasa Indonesia SMP kelas VIII. Melalui kompetensi ini, siswa diharapkan dapat mengungkapkan pikiran dan perasaan dalam puisi. Melalui puisi siswa diharapkan dapat menyalurkan pikiran dan perasaan secara estetik, termasuk menyampaikan kritik sosial.

Meskipun telah ditetapkan dalam kurikulum tentang pengajaran sastra, seringkali masih ditemui kasus di kelas terkait kesulitan siswa dalam mengeksplorasi ide. Pembelajaran yang diterapkan oleh guru telah cukup inovatif dengan menerapkan model pembelajaran kooperatif dalam pengajaran. Namun demikian, kemampuan menulis puisi siswa masih mengalami kendala. Kendala yang dihadapi siswa tersebut ditemui ketika peneliti melakukan studi pendahuluan di SMP Negeri 22 Makassar. Kendala-kendala tersebut, yaitu (1) keterbatasan siswa dalam mengembangkan ide menjadi sebuah puisi karena minim diksi dan menganggap puisi itu harus dibuat dengan diksi kata berupa sajak-sajak yang sulit, (2) siswa merasa kesulitan menemukan ide, dan (3) siswa cenderung terpaku dalam penentuan judul terlebih dahulu sebelum menulis puisi, sementara mereka masih merasa kebingungan dalam menentukan sebuah judul. Kendala-kendala tersebut merupakan kendala teknis yang dialami siswa. Selain itu, persoalan konsep pemahaman mereka terhadap puisi juga masih minim sehingga penulisan puisi cenderung dibuat dalam bentuk cerita berparagraf. Temuan-temuan tersebut menunjukkan bahwa kemampuan siswa menulis puisi di sekolah ditemukan masih rendah. Untuk itulah, kasus tersebut kemudian dijadikan fokus penelitian ini.

Menghadapi kenyataan menulis puisi siswa yang masih mengalami kendala tersebut, diperlukan sebuah pemecahan untuk mengatasinya. Guru dapat menggunakan berbagai metode, teknik, ataupun pemodelan untuk mengatasi permasalahan yang dialami oleh siswa tersebut. Dalam penelitian ini, penulis menggunakan teknik akrostik sebagai alternatif pemecahan masalah berdasarkan kasus yang ditemui di kelas berdasarkan observasi. Puisi akrostik ini cocok digunakan di kalangan siswa karena puisi akrostik cenderung sederhana sehingga membantu siswa sebagai pemula dalam menulis puisi. Teknik akrostik dapat membantu siswa mengatasi persoalan teknis yang mereka hadapi.

Keefektifan penggunaan teknik akrostik dalam meningkatkan kemampuan menulis puisi telah dibuktikan oleh peneliti terdahulu, yakni Herawati (2010) yang melakukan penelitian eksperimen dengan menggunakan teknik akrostik. Hasil penelitiannya menunjukkan bahwa teknik akrostik efektif digunakan dalam pembelajaran puisi. Hal ini dilihat dari temuan data mengenai kemampuan menulis puisi siswa yang lebih tinggi ketika menggunakan teknik akrostik dibandingkan siswa yang tidak menggunakan teknik akrostik. Al-Hajj (2005) dalam penelitiannya juga juga menemukan bahwa penggunaan strategi akrostik dalam pembelajaran menulis puisi dapat menunjukkan hasil positif. Hasil-hasil penelitian tersebut mengindikasikan bahwa teknik akrostik merupakan salah satu teknik yang andal dan dapat digunakan untuk meningkatkan keterampilan siswa menulis puisi. Hasil itu menjadi dasar pelaksanaan penelitian tindakan ini. 
Berbeda dengan penelitian terdahulu, penelitian ini didesain dengan penelitian tindakan kelas. Fokus penelitian ini adalah proses pembelajaran yang dikembangkan guru dalam meningkatkan kemampuan siswa menulis puisi. Proses pembelajaran yang dikembangkan dalam tahapan-tahapan dan langkah teknis dapat membantu guru mengembangkan pembelajaran puisi dengan teknik akrostik.

Harley dan Noyes (2009) mengungkapkan bahwa akrostik menggunakan nama kunci atau ungkapan yang ditulis secara vertikal dan setiap baris puisi dimulai dengan huruf awal dari nama kunci atau ungkapan tersebut. Berdasarkan pengertian tersebut, dapat diketahui bahwa menulis puisi dengan teknik akrostik yaitu menulis puisi dengan menggunakan huruf dalam sebuah kata untuk memulai tiap-tiap baris dalam puisi. Kata tersebutlah yang menjadi judul dalam puisi kemudian ditulis vertikal, sehingga setiap hurufnya dikembangkan menjadi bait-bait puisi.

Menulis puisi dengan menggunakan teknik akrostik dapat memberikan pengalaman menulis yang menyenangkan dan tersistematis bagi siswa. Siswa dapat memainkan huruf-huruf yang membentuk sebuah kata untuk dikembangkan menjadi sebuah puisi yang menarik. Frye, Trathen, \& Schahal (2010:592) mengemukakan bahwa sebuah puisi dengan teknik akrostik cenderung singkat dan tidak memerlukan sajak dalam membuatnya. Penulisan puisi akrostik awalnya berkembang di Yunani kuno. Puisi akrostik adalah bentuk puisi yang unik dengan fokus pada huruf awal yang memberikan inspirasi.

Berdasarkan uraian tersebut, penelitian tindakan kelas (classroom action research) ini bertujuan untuk mendeskripsikan peningkatan proses dan hasil pembelajaran menulis puisi dengan menggunakan teknik akrostik.

\section{METODE}

Jenis penelitian ini adalah jenis penelitian tindakan kelas (classrooom action research). Mekanisme pelaksanaannya dilakukan dalam dua siklus yang setiap siklusnya dilakukan dengan empat tahap, yaitu tahap perencanaan, pelaksanaan, observasi, dan refleksi. Penelitian yang dilakukan merupakan penelitian tindakan kelas yang berpola terintegrasi. Pada pola ini, sebelum melaksanakan tindakan, peneliti terlebih dahulu melakukan diskusi kepada guru untuk menyama- kan persepsi terhadap langkah-langkah pelaksanaan tindakan yang akan dilakukan. Perencanaan tindakan pada setiap siklus dilakukan dua kali pertemuan. Masing-masing pertemuan dilaksanakan dalam waktu $2 \times 40$ menit.

Subjek penelitian pada penelitian ini adalah seorang guru bahasa Indonesia dan siswa kelas VIII SMP Negeri 22 Makassar dengan jumlah siswa yang terdiri atas 40 orang siswa. Data penelitian berupa data proses dan hasil pembelajaran. Data penelitian diperoleh melalui observasi, wawancara, dan evaluasi tes dari setiap tindakan pembelajaran menulis puisi dengan menggunakan teknik akrostik. Data proses pembelajaran ini berkaitan dengan penerapan teknik akrostik dalam pembelajaran menulis puisi. Data tersebut diperoleh berdasarkan hasil observasi terhadap kegiatan guru dan siswa selama proses pembelajaran menulis puisi berlangsung. Selain itu, data juga diperoleh dari hasil wawancara terhadap siswa untuk mengetahui tanggapan mereka setelah mengikuti pembelajaran menulis puisi dengan teknik akrostik. Selanjutnya, data hasil pembelajaran meliputi hasil unjuk kerja dan evaluasi tes yang diperoleh dari hasil menulis puisi dengan menggunakan teknik akrostik.

Teknik yang digunakan untuk menganalisis data penelitian ini adalah teknik analisis deskriptif. Teknik deskriptif digunakan untuk menggambarkan perubahan sikap dan perilaku siswa dan guru dalam proses pembelajaran menulis puisi melalui teknik akrostik dan mengacu pada data nontes yang berupa observasi dan wawancara. Teknik ini juga digunakan untuk menganalisis hasil unjuk kerja menulis puisi dan evaluasi tes siswa di setiap siklus.

\section{HASIL DAN PEMBAHASAN}

Hasil dan pembahasan diuraikan dengan fokus pada pendeskripsian upaya meningkatkan kemampuan menulis puisi dengan teknik akrostik. Uraian hal tersebut dibagi dalam tiga bagian, yaitu: (1) pelaksanaan tindakan, (2) peningkatan proses pembelajaran menulis puisi melalui teknik akrostik, dan (3) hasil pembelajaran menulis puisi melalui teknik akrostik.

\section{Pelaksanaan Tindakan}

Prosedur pelaksanaan penelitian tindakan kelas terdiri dari empat fase dalam setiap siklus 
dan dilaksanakan sesuai dengan perubahan yang ingin dicapai. Berikut paparan prosedur pelaksanaan penelitian yang dilakukan.

\section{Perencanaan}

Pada tahap perencanaan dilakukan kegiatan, meliputi (1) membuat rencana pelaksanaan pembelajaran (RPP) untuk setiap pertemuan; (2) mempersiapkan sumber dan bahan yang akan diberikan; (3) mengembangkan bahan ajar sesuai materi yang akan diajarkan dengan menggunakan teknik akrostik; (4) membuat lembar obsevasi untuk siswa dan guru selama proses pembelajaran berlangsung; dan (5) membuat dan menyusun butir-butir soal atau format evaluasi untuk tes pada siklus pertama.

\section{Pelaksanaan}

Pada tahap ini guru melakukan pelaksanaan pembelajaran sesuai yang telah direncanakan dalam RPP, yakni (1) menyampaikan tujuan menulis puisi dengan menggunakan teknik akrostik. (2) siswa diajak untuk mengenali puisi; (3) siswa diarahkan untuk mendengarkan penjelasan tentang materi teknik akrostik dan berbagai contoh puisi yang menggunakan teknik akrostik; (4) siswa diarahkan untuk menentukan satu judul puisi dengan melakukan pengamatan secara langsung terhadap objek-objek yang ada di sekitar siswa. Baik objek benda hidup maupun benda mati. Selain itu, peristiwa atau kejadian yang terjadi di sekitar siswa juga dijadikan sebagai media pembelajaran yang diamati secara langsung; (5) setelah menemukan judul yang tepat, siswa mengembangkan judul puisi tersebut menjadi sebuah puisi yang utuh sesuai dengan teknik akrostik yang telah dijelaskan; dan (6) memantau keaktifan dan kesungguhan siswa dalam proses pembelajaran berdasarkan pedoman observasi.

\section{Observasi}

Observasi dilakukan untuk mengamati hasil atau dampak dari tindakan yang dilaksanakan atau dikenakan terhadap siswa. Pelaksanaan observasi ditujukan kepada aktivitas siswa dan guru dengan berpedoman kepada format observasi yang sudah dipersiapkan. Peneliti melakukan pengamatan dan mencatat semua proses yang terjadi dalam tindakan pembelajaran, diskusi antara guru dan peneliti tentang pelaksanaan tindakan yang akan dilakukan, mencatat semua kelemahan, baik ketidaksesuaian antara tindakan maupun respons siswa yang berbeda dengan yang diharapkan. Setelah itu, peneliti melakukan analisis terhadap tindakan-tindakan yang telah dilaksanakan.

Refleksi

Langkah terakhir yang dilakukan adalah mengadakan refleksi terhadap hasil yang telah dicapai pada pemberian tindakan. Kegiatan yang dilakukan, yakni (1) melakukan evaluasi terhadap tindakan yang telah dilakukan dan berdiskusi bersama guru mengenai tindakan yang telah diberikan; (2) jika masih ditemukan masalah-masalah pada tindakan dan hasil yang dicapai pada siklus I (pertama) belum sesuai indikator dan target yang direncanakan maka akan dimusyawarahkan bersama guru alternatif pemecahannya dan selanjutnya direncanakan tindakan berikutnya di siklus II. Tahapan pelaksanaan di siklus II secara umum mengulang tahapan-tahapan yang sama dengan siklus I, namun dengan perbaikan-perbaikan yang disesuaikan dengan hasil evaluasi pelaksanaan di siklus I dan berdasarkan diskusi bersama guru.

\section{Peningkatan Proses Pembelajaran Menulis Puisi melalui Teknik Akrostik}

Berdasarkan studi pendahuluan yang dilakukan sebelum melakukan penelitian, diketahui bahwa di dalam proses pembelajaran masih terdapat hal-hal yang harus dibenahi untuk meningkatkan kualitas pembelajaran. Rumusan tujuan pembelajaran yang dicapai adalah melalui kegiatan pembelajaran siswa diharapkan dari aspek kognitif dapat (1) memahami pengertian puisi dengan baik dan benar, (2) memahami unsur pembangun puisi dengan baik dan benar, dan (3) menemukan sebuah ide untuk menulis puisi melalui kegitan pembelajaran dengan baik. Aspek psikomotorik diharapkan siswa dapat menulis sebuah puisi dengan menggunakan pilihan kata yang sesuai. Dari aspek afektif, (1) siswa terlibat aktif dalam pembelajaran dengan berperilaku aktif, kreatif, percaya diri, responsif, dan apresiatif dan (2) siswa terlibat aktif dalam pembelajaran dengan berbicara dengan bahasa yang baik dan benar, menghargai sesama teman, dan menjadi pendengar yang baik.

Pada pelaksanaan tindakan siklus I, kegiatan pembelajaran dilakukan dengan mengikuti 
langkah-langkah penulisan puisi dengan menggunakan teknik akrostik, yaitu penggalian ide, penentuan ide, penulisan ide, dan penyajian. Metode yang digunakan selama proses pembelajaran adalah ceramah, tanya jawab, dan penugasan. Kegiatan pembelajaran dilakukan melalu tiga tahap, yakni pendahuluan, kegiatan inti, dan penutup.

Berdasarkan hasil refleksi pada siklus I, masih terdapat hal-hal yang menyebabakan proses pembelajaran kurang efektif, di antaranya: (1) guru kurang memberikan kesempatan kepada siswa untuk menyampaikan tanggapannya dalam proses pembelajaran, (2) guru kurang mendampingi dan mengarahkan siswa dalam aktivitas penggalian ide, penentuan ide, dan penulisan puisi, (3) sebagian besar siswa masih tidak percaya diri menyampaikan pendapatnya dalam pembelajaran karena tidak terbiasa dari aktivitas sebelumnya sehingga siswa perlu dimotivasi agar berani mengemukakan pendapatnya dan tidak takut salah, (4) masih ada siswa yang meniru puisi karya teman sebangkunya sehingga pengawasan dan motivasi diperlukan agar siswa lebih percaya diri membuat hasil karyanya sendiri, dan (5) pada kegiatan menulis puisi, siswa masih kelihatan bingung dalam melakukan langkah-langkah pembelajaran dengan teknik akrostik dan media objek langsung. Selain itu, masih ada langkah-langkah pembelajaran yang tidak dilaksanakan oleh guru. Adanya kendala-kendala tersebut menyebabkan indikator keberhasilan belum tercapai pada siklus I sehingga penelitian dilanjutkan pada siklus II. Jika dipersentasekan, ketuntasan belajar siswa pada siklus I sebesar $67,7 \%$.

Tabel 1. Perubahan Data Pelaksanaan Pembelajaran Siklus I Ke Siklus II

\begin{tabular}{cc}
\hline Siklus & $\begin{array}{c}\text { Ketuntasan Aktivitas Belajar } \\
\text { Siswa }\end{array}$ \\
\hline I & $67,7 \%$ \\
\hline II & $80 \%$ \\
\hline $\begin{array}{c}\text { Peningkatan } \\
\text { Proses }\end{array}$ & $12,3 \%$ \\
\hline
\end{tabular}

Setelah melakukan evaluasi dan melanjutkan penelitian pada siklus II, terjadi peningkatan proses pembelajaran dari siklus I ke siklus II. Hal ini terlihat dari hasil observasi siswa dan guru. Aktivitas guru yang tidak terlaksana di siklus I sudah dilakukan dan dibenahi pada siklus II ini.
Guru lebih maksimal mendampingi siswa pada pelaksanaan setiap langkah dalam skenario pembelajaran. Oleh karena itu, aktivitas siswa lebih maksimal dan terarah. Pada siklus II ini siswa juga sudah menunjukkan sikap yang lebih percaya diri dan lebih menghargai temannya. Perubahan tersebut dapat dilihat pada tabel berikut ini.

\section{Peningkatan Hasil Pembelajaran Menulis Puisi melalui Teknik Akrostik}

Data hasil dari siklus I ke siklus II menunjukkan bahwa hasil tes kemampuan menulis puisi keempat puluh orang siswa setelah pembelajaran mengalami perubahan. Hasil analisis kemampuan menulis puisi dilihat dari segi keterkaitan objek dengan isi puisi, diksi atau pilihan kata, tipografi atau bentuk puisi, amanat, dan pengimajian. Penerapan teknik akrostik mampu meningkatkan hasil pembelajaran menulis puisi siswa. Hal tersebut dapat dilihat dari tabel berikut.

Tabel 2. Perubahan Persentase Kuantitatif Perolehan Nilai Hasil Menulis Puisi

\begin{tabular}{cc|c}
\hline \multicolumn{2}{c|}{ Persentase Perolehan Nilai } & \multirow{2}{*}{ Siklus } \\
\cline { 1 - 2 } $\begin{array}{c}\text { Nilai 70 ke } \\
\text { atas }\end{array}$ & $\begin{array}{c}\text { Nilai di } \\
\text { bawah 70 }\end{array}$ & \\
\hline $67 \%$ & $33 \%$ & I \\
\hline $93 \%$ & $7 \%$ & II \\
\hline
\end{tabular}

Tabel 2 menunjukkan peningkatan secara signifikan nilai hasil belajar siswa. Jumlah siswa yang memperoleh nilai kurang dari 70 berkurang $26 \%$. Pada hasil evaluasi tes kognitif siswa di siklus I sudah menunjukkan hasil yang sesuai dengan indikator keberhasilan penelitian yang ditetapkan sehingga tidak perlu lagi dilanjutkan pada siklus II karena dianggap telah berhasil seperti ditunjukkan pada Tabel 3 .

Tabel 3. Perolehan Nilai Hasil Evaluasi Tes Siswa

\begin{tabular}{cc}
\hline Perolehan Nilai & Persentase \\
\hline Nilai 70 ke atas & $79 \%$ \\
\hline Nilai di bawah 70 & $21 \%$ \\
\hline Jumlah & $\mathbf{1 0 0 \%}$
\end{tabular}

Berdasarkan Tabel 3, hasil perolehan nilai evaluasi tes siswa secara kuantitatif dapat dilihat bahwa siswa yang mendapatkan nilai $70 \mathrm{ke}$ atas 
sebanyak 79\%. Lalu, siswa yang mendapatkan nilai di bawah 70 sebanyak 21\%. Hasil evaluasi tes siswa tersebut sudah mencapai indikator keberhasilan yang telah ditetapkan, yakni $75 \%$ atau lebih siswa telah mencapai ketuntasan minimal (KKM) 70. Berdasarkan perolehan tersebut, indikator keberhasilan siswa menjawab pertanyaan dalam soal evaluasi dianggap sudah tuntas memenuhi kriteria yang ditetapkan dan tidak perlu dilanjutkan pada siklus berikutnya.

\section{Pembahasan}

Paparan hasil penelitian menunjukkan peningkatan proses dan hasil pembelajaran dari siklus II. Peningkatan yang dicapai merupakan hasil perbaikan proses pembelajaran menulis puisi melalui teknik akrostik. Guru telah mengoptimalkan perbaikan proses pembelajaran terhadap segala kekurangan pada siklus satu dan juga lebih maksimal dalam mendampingi siswa pada pelaksanaan setiap langkah dalam skenario pembelajaran sehingga proses pembelajaran pada siklus dua berlangsung lebih terarah dan jelas. Aktivitas guru yang tidak terlaksana di siklus satu telah dilakukan dan dibenahi pada siklus dua. Penyajian materi pembelajaran oleh guru di siklus dua disampaikan lebih interaktif dan lebih banyak menstimulasi siswa untuk aktif memberikan tanggapan. Guru menciptakan situasi kelas yang tidak menegangkan bagi siswa sehingga siswa dapat lebih mudah mengerti dan pembelajaran lebih efektif. Efek yang diberikan adalah pencapaian hasil siswa dalam menulis puisi mengalami peningkatan yang lebih baik dengan meningkatnya nilai rata-rata siswa dalam menulis puisi dibandingkan dengan siklus pertama.

Dari aspek sikap siswa, di siklus dua ini peningkatan dapat terlihat pada sikap kurang percaya diri, kemampuan bekerja sama, dan saling menghargai yang tidak muncul di siklus pertama sudah dimunculkan pada siklus dua. Dari aspek kognitif, siswa yang mendapat pengulangan materi yang sama terkait puisi menjadi lebih memahami terhadap teori. Tidak ditemukan kendala berarti dalam aspek ini. Sejak siklus pertama, siswa sudah memenuhi standar kriteria penilaian yang telah ditentukan. Nilai yang dihasilkan siswa sudah memenuhi standar nilai di atas 70 . Meskipun demikian, penguasaan terhadap materi ini tetap penting untuk meningkatkan hasil pembelajaran. Pentingnya penguasaan terhadap teori dikemukakan oleh Asri (2017:6). Berdasarkan hasil penelitiannya disimpulkan bahwa penguasaan terhadap teori puisi mempunyai hubungan yang signifikan dengan keterampilan menulis puisi.

Ketidakberhasilan mencapai kriteria ketuntasan pada siklus I disebabkan oleh kurang efektifnya proses pelaksanaan pembelajaran yang dilakukan sehingga berdampak pada aktivitas dan hasil belajar siswa yang belum mencapai krtiteria ketuntasan. Berdasarkan hal tersebut, dapat disimpulkan bahwa hasil belajar menulis puisi siswa dipengaruhi oleh adanya relevansi antara proses pelaksanaan pembelajaran dengan hasil belajar siswa. Proses pembelajaran yang dilakukan secara maksimal oleh guru dan penerapan teknik pembelajaran yang sesuai akan berdampak pada hasil menulis puisi siswa yang lebih baik. Sebagaimana penelitian yang dilakukan oleh Fitri (2017:53) yang menunjukkan hasil yang berbeda pada siklus dua setelah memaksimalkan pembelajaran. Suasana pembelajaran mengalami perubahan positif yang signifikan. Terjadi suasana pembelajaran yang efektif dan menyenangkan bagi siswa. Minat dan motivasi siswa dalam belajar sangat tinggi yang ditunjukkan oleh reaksi siswa dalam belajar.

Hasil penelitian pada siklus dua menunjukkan pencapaian hasil belajar siswa dengan menerapkan teknik akrostik yang dilakukan secara optimal dapat meningkat dari siklus pertama. Hasil tersebut disimpulkan sebagai keunggulan pembelajaran puisi dengan teknik akrostik. Berdasarkan hasil penelitian, keunggulan teknik akrostik adalah (1) memberikan kemudahan kepada siswa dalam menemukan ide tulisan karena bentuk puisi akrostik sederhana; (2) memberikan kemudahan kepada siswa dalam mengembangkan ide dan menulis puisi karena terbantu oleh hurufhuruf awal yang disusun secara vertikal; dan (3) memudahkan siswa dalam menyusun kosakata karena dapat mengambil ide tulisan dari hal-hal yang dekat dengan siswa; (4) judul yang sekaligus dapat disusun secara vertikal untuk dikembangkan menjadi isi puisi membuat teknik akrostik ini lebih efektif dan menolong siswa yang kesulitan menentukan judul ataupun yang terpaku pada judul, namun kesulitan mengembangkan isi puisi. Keunggulan tersebut diungkapkan juga oleh Frye (2010) dalam penelitannya yang menyatakan bahwa teknik akrostik ini adalah teknik yang sederhana dan memudahkan siswa dalam menulis puisi. Kemudahan itu mencakup mencari dan mengembangkan ide. 
Selain keunggulan yang dimiliki teknik akrostik tersebut, dalam proses pembelajaran yang telah dilakukan, ada tindakan-tindakan yang menjadi strategi bagi guru yang membuat hasil pembelajaran menulis puisi menjadi lebih baik. Hal itu pula yang membuat penelitian ini berbeda dari penelitian terdahulu yang dilakukan oleh Herawati (2010) dan Al-Hajj (2005) meski hasil penelitian ini sejalan dengan keduanya. Hasil penelitian Herawati yang dilakukan dengan metode eksperimen menunjukkan temuan data mengenai kemampuan menulis puisi yang lebih tinggi ketika menggunakan teknik akrostik dibandingkan kelas yang tidak menggunakan teknik akrostik. Begitu pula degan penelitian yang dilakukan oleh Al-Hajj yang juga menunjukkan hasil yang positif dengan meningkatnya kemampuan siswa. Dalam penelitian ini, selain teknik akrostik yang digunakan sesuai langkah-langkah yang sudah ada, penelitian juga menekankan pada pentingnya memberikan bimbingan dan motivasi yang terus-menerus dilaksanakan sehingga menjadi faktor pendukung yang mampu meningkatkan hasil belajar siswa dalam proses pembelajaran menulis puisi. Dengan memperhatikan kesiapan belajar siswa terlebih dahulu, salah satunya dengan menggiring mereka memasuki zona alfa, akan membuat pembelajaran berlangsung efektif dan suasana kelas menjadi lebih kondusif. Sebagaimana yang dikemukakan oleh Chatib (2011: 91) bahwa zona alfa adalah kondisi terbaik untuk belajar siswa. Zona alfa adalah kondisi rileks dan menyenangkan sehingga dapat dibutuhkan oleh siswa untuk mulai menerima pembelajaran pada kondisi ini. Hal ini akan memudahkan dan membuat mereka lebih siap untuk memasuki pelajaran. Penggunaan yel-yel dan permainan dalam kelas juga membuat siswa lebih rileks dan pembelajaran berlangsung lebih menyenangkan. Selain itu, penggunaan mading di dalam penelitian ini sebagai salah satu alat untuk memberikan reward atau penghargaan terhadap hasil karya siswa juga sangat baik dalam meningkatkan motivasi belajar siswa.

Strategi-strategi yang yang digunakan tersebut menjadikan proses pembelajaran lebih kondusif bagi siswa. Frye (2010:591) sendiri menjelaskan bahwa mempelajari puisi dengan menggunakan teknik akrostik yang dikombinasikan dengan model mengajar guru akan menciptakan suatu jembatan pembantu untuk siswa. Dengan demikian, dapat disimpulkan bahwa penerapan teknik akrostik yang dipadukan dengan model mengajar atau strategi-strategi yang menarik bagi siswa dapat membantu mereka untuk belajar lebih efektif dan maksimal.

Selain keunggulannya, teknik akrostik dalam pembelajaran menulis puisi juga memiliki kelemahan. Berdasarkan hasil penelitian ditemukan kelemahan-kelemahan, yaitu (1) puisi yang dihasilkan terlalu sederhana dengan bahasa yang kurang bersajak; (2) membutuhkan keahlian untuk menghubungkan dan merangkai kata menjadi bermakna dalam menyusun tiap larik puisi karena sudah diawali dengan huruf yang disusun secara vertikal. Kelemahan itu dapat diatasi dengan bimbingan khusus untuk mengembangkan kata yang memiliki ketidaklangsungan makna.

Kelemahan yang ditemukan dalam penelitian ini relevan dengan temuan Frye (2010:595) yang mengatakan bahwa penggunaan teknik akrostik ini masih memerlukan strategi yang bisa membantu siswa untuk mengembangkan bahasa puisi menjadi lebih memperhatikan keindahan rasa atau lebih puitis. Oleh karena itu, untuk memaksimalkan pemanfaatannya dalam pembelajaran, teknik akrostik ini perlu diintegrasikan dengan teknik lainnya. Dengan demikian, kelemahan dilengkapi melalui penggunaan teknik lainnya.

\section{SIMPULAN}

Berdasarkan rumusan masalah, hasil penelitian, dan pembahasan dalam penelitian ini, dapat disimpulkan bahwa penerapan teknik akrostik pada pelajaran Bahasa Indonesia dapat meningkatkan kemampuan menulis puisi. Hal ini sesuai dengan hasil penelitian yang dilaksanakan pada siklus I dan siklus II yang menunjukkan bahwa perolehan skor proses dan hasil pembelajaran meningkat. Teknik akrostik yang digunakan dalam penelitian ini akan lebih efektif diterapkan dalam pembelajaran apabila dilakukan dengan mengintegrasikan pengalaman belajar siswa di sekolah. Mereka dapat menggunakan berbagai topik untuk menulis puisi dengan mensintesis pengalaman dan informasi yang mereka ketahui.

Untuk penelitian selanjutnya, disarankan menggunakan teknik akrostik yang dikombinasikan dengan model pembelajaran lain ataupun media pembelajaran oleh guru agar memberikan kemudahan kepada siswa. Hal ini berguna untuk mengembangkan gagasan dan menemukan pilihan kata yang menarik dan makna lebih mendalam. 


\section{UCAPAN TERIMA KASIH}

Penulis menyampaikan ucapan terima kasih kepada Lembaga Pengelola Dana Pendidikan (LPDP) atas dukungan yang diberikan kepada penulis sehingga dapat menempuh pendidikan ma-

\section{DAFTAR PUSTAKA}

Al-Hajj, I. 2005. Strategi Menulis Puisi Akrostik sebagai Upaya Meningkatkan Keterampilan Menulis Puisi Siswa Kelas VII SMPN 2 Kendari. Tesis. Makas sar: UNM.

Atmazaki. 2013. Mengungkap Masa Depan: Inovasi Pembelajaran Bahasa Indonesia dalam Konteks Pengembangan Karakter Cerdas. Makalah. Padang: UNP.

Asri, A. 2017. Korelasi Penguasaan Teori Puisi dengan Keterampilan Menulis Puisi Mahasiswa Program Studi Pendidikan Bahasa dan Sastra Indonesia Fakultas Bahasa san Sastra Universita Negeri Makassar Angkatan 2015. Retorika, 10 (1): 1-7.

Chatib, M. 2011. Gurunya Manusia. Bandung: Kaifa.

Fitri, S. 2017. Peningkatan Kemampuan Menulis Puisi dengan Menggunakan Metode Kooperatif Tipe Think Pair Share (Berpikir, Berpasangan, Dan Berbagi) pada Sis wa Kelas VIII SMP Negeri 4 Bulukumba. Retorika, 10 (1): 49-55. gister di Program Studi Pendidikan Bahasa Indonesia, Sekolah Pascasarjana Universitas Pendidikan Indonesia. Ucapan terima kasih disampaikan pula kepada mitra bestari (reviewers) yang telah memberikan saran, kritik, dan rekomendasi perbaikan artikel ini.

Frye, E. M., W. Trathen, \& B. Schlagal. 2010. "Extending Acrostic Poetry Into Content Learning: A Scaffolding Framework". The Reading Teacher, 63 (7): 591-595.

Harley, A., \& Noyes, D. 2009. African Acrostics: A Word In Edgeways. Somerville, MA: Candlewick. Frye, Elizabeth M., Woodrow Trathen, \& Bob Schlagal. 2010. Extending Acrostic Poetry Into Conten Learning: A Scaffolding Framework. The Reading Teacher. 63 (7): 591-595.

Herawati. 2010. Penerapan Penggunaan Strategi Akrostik dalam Pembelajaran Menulis Puisi Siswa Kelas VIII SMP Negeri 1 Bontomatene Kabupaten Selayar. Skripsi. Makassar: FBS UNM.

Nurgiyantoro, B. \& A. Efendi. 2013. Prioritas Penentuan Nilai Pendidikan Karakter dalam Pembelajaran Sastra Remaj. Cakrawala Pendidikan, 32 (3): 382-393. 